\title{
Metabolomic profiling of cancer cells to Aloe vera extract by ${ }^{1} \mathrm{HNMR}$ spectroscopy
}

Seyedeh Masoomeh Noorolahi' ${ }^{1}$, Sedigheh Sadeghi², Maryam Mohammadi², Mahsa Azadi², Nowrooze Ali Rahimi², Farideh Vahabi², Mohammad Arjmand ${ }^{2}$, Haj Hosseini², Samaneh Mosallatpur ${ }^{1}$ and Zahra Zamani ${ }^{2 *}$

*Correspondence: zamani@pasteur.ac.ir

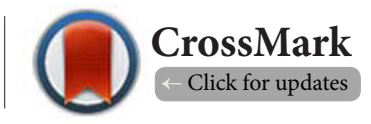

'Department of Biochemistry, Payame Noor university, Tehran, Iran.

${ }^{2}$ Department of Biochemistry, Pasteur Institute of Iran, Tehran, Iran.

\begin{abstract}
Background: The modern life style despite its comforts has made cancer a leading public health problem. As chemotherapeutics has many side effects including resistance, recent attention has focused on plants which may provide a good opportunity for complementary cancer treatment. Aloe vera has been described as a wonder plant due to its many advantages. It has been reported to have anticancer properties. Metabolomics is the measurement and analysis of metabolites in a biological sample by the use of throughput technology like ${ }^{1} \mathrm{HNuclear}$ Magnetic Resonance and Mass Spectrometry. The results are analyzed by multivariate analysis methods. The metabolome reveals the final interaction between the genome of an organism and its environment. We studied the inhibitory effects and metabolomic profile of Aloe Vera extract on Raji cells (cancerous lymphoma cells) using ${ }^{1}$ HNMR spectroscopy.

Methods: The gel was removed from Aloe vera leaves by a sharp knife and chopped by a blender, warmed to $50^{\circ} \mathrm{C}$ with ascorbic acid as antioxidant and finally cooled to almost $20^{\circ} \mathrm{C}$. After filtering, the gel was lyophilized and dissolved in RPMI medium $(2 \mathrm{mg} / \mathrm{ml})$ and added to Raji cells and $50 \%$ inhibitory concentration determined by MTT. Large scale culture of Raji cells were carried out using $50 \%$ inhibitory concentration dose of Aloe vera gel. The Raji cells were collected, metabolites extracted using water or chloroform/methanol, lyophilized and sent for ${ }^{1} \mathrm{HNuclear}$ magnetic resonance analysis by NOESY technique.
\end{abstract}

Results: $50 \%$ inhibitory concentration of Aloe vera was seen to be $40 \mu \mathrm{g} / \mathrm{ml}$. The differentiating metabolites were identified and the metabolic cycles were detected.

Conclusions: Changes were observed mainly in the amino acid metabolites and the main metabolic cycles involved were protein biosynthesis, mitochondria transport chain, catecholamine biosynthesis and pentose phosphate pathway.

Keywords: Metabolomics, Aloe Vera, Raji cells, ${ }^{1} \mathrm{HNMR}$ spectroscopy

\section{Introduction}

Aloe Vera is a plant that belongs to the Aasphodelacea (Liliaceae) family has been used as an herbal medicine for centuries. It is native to Africa and many Mediterranean countries and is used for several healing purposes, like treating various skin disorders such as abcesses, burns and eczema. Its juice may help people with ulcerative colitis, an inflammatory bowel disease. Aloe Vera has been used as a remedy for coughs, wounds, diabetes, gastritis, headaches, arthritis, ulcers, cancer and also immunesystem deficiencies [1]. There are over 100 active biological components found in Aloe Vera, including: anthraquinones, vitamins, minerals, enzymes, amino acids, polysaccharides and plant sterols [2].

Cancer after cardiovascular disease is the second leading cause of death in the world. Approximately 10 million people are diagnosed with it every year and 6 million die of it [3]. Treatment options for cancer include chemotherapy, surgery, radiation and immunotherapy. The use of any of these treatments depends upon the location, grade, tumor stage as well as the general state of a person's health. Chemotherapy and 
Noorolahi et al. Journal of Metabolomics 2016,

radiation in addition to cancer cells, destroy normal cells [4] and recently resistance to chemotherapeutic drugs has been reported in some cases and this has renewed an interest in alternative and herbal methods to complement conventional treatment. In fact, medicinal plants are more available, cheaper and possess less toxicity compared to modern(allopathic) drugs. Biological active components of plants can be important sources for new drugs which may lead to new and better treatments for cancer [3].

In this study, Raji cells were used as a model system to study the anti-cancer properties of Aloe vera. Raji cells are a series of cell lines derived from $B$ lymphocyte of a patient with Burkitt's lymphoma (BL) which is an aggressive form of B cell non Hodgkin's lymphoma [5] with reports of chemotherapy resistance.

Metabolomics comprehensively analyzes hundreds of metabolites in a biological sample simultaneously using high throughput technology. Mass spectrometry (MS) and ${ }^{1} \mathrm{HNuclear}$ Magnetic Resonance spectroscopy ('HNMR) are used in the measurement of metabolites in the sample with chemometrics analysis. Although metabolomics comprises the smallest domain (approximately 5, 000 metabolites) as compared to genomics (30,000 genes) and proteomics $(100,000$ or more proteins), it is more diverse and involves many different biological molecules, making it chemically and physically more complex than the other two. The importance of metabolomics is in disease diagnosis and drug discovery as the changes in the metabolome are a direct outcome from perturbations in cellular activity [6].

The purpose of this research is to study the effect of Aloe vera gels on Raji cells and to obtain the difference in their metabolic pattern by ${ }^{1} \mathrm{HNMR}$ spectroscopy so as to identify metabolites and modified metabolic cycles. Earlier work has been done on the effect of ginger on the metabolic pattern of Raji cells and the pathways detected were mainly glucose cycles $[6,7]$.

\section{Materials and methods}

Preparation of Aloe vera extract

Aloe vera leaves were prepared fresh from herbarium and identified by Tehran University. They were first washed with a solution of sodium hypochloride and rinsed with distilled water at room temperature for $4 \mathrm{~h}$. A sharp knife was used for separation of the leaf crusts and the gel collected by a spatula-like knife gel from the lower crust. The gels were chopped by a blender and warmed to $50^{\circ} \mathrm{C}$ using ascorbic acid as antioxidant and then cooled to $20^{\circ} \mathrm{C}$. The Aloe Vera extract was filtered through gauze and the filtrate lyophilized [8].

\section{Cell culture}

The Raji cell lines (B-cell lymphoma) were purchased from Pasteur Institute of Iran. The cells were obtained from NCBI code $\mathrm{C} 127$ with ATCC number CCL-86, but are DNA typed and karyotyped periodically by the Pasteur Institute of Iran. The culture medium contained $10 \%$ fetal calf serum and RPMI1640 , penicillin and streptomycin and incubated at $37^{\circ} \mathrm{C}$ with $5 \% \mathrm{CO} 2$ at $95 \%$ humidity in a $25 \mathrm{~cm}^{2}$ flask [9]

\section{$50 \%$ inhibitory concentration (IC50)}

$1 \mathrm{~mL}$ of culture medium containing $1.6 \times 10^{4}$ Raji cells were added to each well and treated with different concentrations of $0.2,2,20,40,100 \mathrm{mg} / \mathrm{ml}$ Aloe Vera extract with duplicates using controls without extract. The cells were treated for 24 , 48,72 hours.

\section{Viability test}

Trypan blue was used to stain dead cells and their viability assessed by counting under an invert microscope using a hemocytometer at 24, 48 and $72 \mathrm{~h}$ [10].

\section{MTT}

[3-(4,5-dimethylthiazol-2-yl)-2,5-diphenyltetrazolium bromide] assay: was performed at 24,48 and $72 \mathrm{~h}$ in 96 -well plates with the same concentrations of Aloe Vera as viability test. At the end of the time periods, the culture medium supernatant was discarded and the cells were incubated with $50 \mu \mathrm{g} / \mathrm{mL}$ MTT stock solution in PBS for 3 to 4 hours at $37^{\circ} \mathrm{C}$. Then, $100 \mu \mathrm{L}$ formazan was added in dimethyl sulfoxide to the wells and shaken for $30 \mathrm{~min}$ and absorbance read at $570 \mathrm{~nm}$ using ELISA Reader (Anthos 2020) [11].

\section{Culture of Raji cells for ${ }^{1} \mathrm{HNMR}$}

After determining IC50 concentration, Raji cells were cultured with IC50 titer of Aloe Vera extract in $75 \mathrm{~cm}^{2}$ flask for $48 \mathrm{~h}$ and then collected by centrifugation at $6,000 \mathrm{Xg}$ for $5 \mathrm{~min}$ and stored in freezing solution containing $90 \%$ Fetal Bovine Serum and $10 \%$ DMSO at $-70^{\circ} \mathrm{C}$.

\section{Cell extraction}

The method of extraction using methanol-chloroform-water was done as described previously. The temperature of the extraction procedure was maintained at $4^{\circ} \mathrm{C}$ by working in a crushed ice bath. Cells were washed in 1 X PBS and centrifuged at $6,000 \mathrm{~g}$ for $5 \mathrm{~min}$ and resuspended in $500 \mu \mathrm{L}$ of ice-cold 2:1 $(\mathrm{v} / \mathrm{v})$ methanol-chloroform solution. It was then transferred into a 1.5mL Eppendorf tube, $250 \mu \mathrm{L}$ of ice-cold H2O 1:1 (v/v) chloroform/H20 was added and vortexed. The cells were sonicated on ice for $10 \mathrm{~min}$ and centrifuged for $5 \mathrm{~min}$ at $18000 \mathrm{Xg}$.

The lower lipophilic and the upper hydrophilic extracts were separated and collected in different Eppendorf tubes and lyophilized and stored at $-20^{\circ} \mathrm{C}$ [7].

\section{Preparation for ${ }^{1} \mathrm{HNMR}$}

Lyophilized hydrophilic cell extracts $(n=10)$ were resuspended in $200 \mu \mathrm{L}$ of buffer $(150 \mathrm{mM}$ potassium phosphate at $\mathrm{pH} 7.4$, $1 \mathrm{mM} \mathrm{NaN3}$, and $0.01 \%$ trimethylsilyl propionate (TSP) (Sigma, CA, USA) in $100 \%$ D2O and the lipophilic cell extracts $(n=10)$ were resuspended in $200 \mu \mathrm{L}$ deuterated chloroform [12]. 
Noorolahi et al. Journal of Metabolomics 2016,

\section{${ }^{1}$ HNMR spectroscopy}

The cell suspensions were placed in $5 \mathrm{~mm}$ probes for analysis and one dimensional spectroscopy was performed on a 'HNMR spectrometer (Bruker AV-500) with filed gradient operating at $500.13 \mathrm{MHZ}$ for observation of proton at 298K. One dimensional ${ }^{1} \mathrm{HNMR}$ spectra were acquired with $6009.6 \mathrm{~Hz}$ spectral width, a $10-\mu$ s pulse $0.1 \mathrm{~s}$ mixing time, 3000 transients and $3.0 \mathrm{~s}$ relaxation delay, with standard 1D NOESY (nuclear Overhauser spectroscopy) pulse sequence to suppress the residual water peak [13]. The ${ }^{1} \mathrm{HNMR}$ spectrum comprising of Fourier Transformed information about metabolites in the control and treated groups(both hydrophilic and lipophilic extracts of each) were imported into MATLAB (v.7.8.0.347) software and first analyzed by ProMetab software (version 1.1) Chemical shifts between 0 and $10 \mathrm{ppm}$ were normalized and spectra binned in 0.004units and the water peak (4.7) removed. The Excel files were then assessed by PLS-Toolbox version 3.0 and Partial Least Square Discriminant Analysis (PLS-DA) was applied [14].

\section{Identification of metabolites}

The differentiating metabolites related to these resonances were identified by chemical shift determination using Human Metabolome Database Data Bank (HMDB) (http://www.hmdb. $\mathrm{ca} /$ metabolites). The metabolic cycles were determined using Metabo-Analyst software (http://www.metaboanalyst.ca/).

\section{Results}

IC50 of Aloe Vera extracton Raji cells is shown to be $40 \mu \mathrm{g} / \mathrm{ml}$ at $48 \mathrm{~h}$ (Figure 1). Superimposed ' $\mathrm{HNMR}$ spectra of hydrophilic layer and lipophilic layer between experimental and control groups can be seen in (Figures $\mathbf{2 A}$ and $\mathbf{2 B}$ ). The analysis of 'HNMR spectra are depicted as score plot (Figures $\mathbf{3 A}$ and $\mathbf{3 B}$ ) and loading plot (Figures $4 A$ and $4 B$ ) of hydrophilic layer and lipophilic layer between experimental and control groups. Altered metabolites of hydrophilic phase and lipophilic phase are identified in Tables 1 and 2 respectively. Metabolite enrichment analysis is shown in Figure 5 and $\mathbf{6}$ depicting the main pathways affected by the extract.

\section{Discussion}

Aloe vera has many beneficial properties. Anti- cancer properties of Aloe vera have been reported from 2010 when its anti-proliferation effects on some types of cancer cells in vitro such as lung, squamous, glioma, and neuro-ectodermal were described $[15,16]$. It also has anti tumorigenic properties and increases expression of $\mathrm{p} 53$ gene and $\mathrm{Bcl} 2$ as demonstrated on human hepatocellular carcinoma cells $[16,17]$. Ehrlich ascites carcinoma in Swiss albino mice were apparently healed by Aloe vera extract by reversion of their hematological profiles towards normal levels and a decrease of peroxidation enzymes of lipid peroxidation and increased the levels of reduced glutathione and other antioxidant enzymes, like superoxide dismutase, catalase and glutathione peroxidase [16]. The anti-

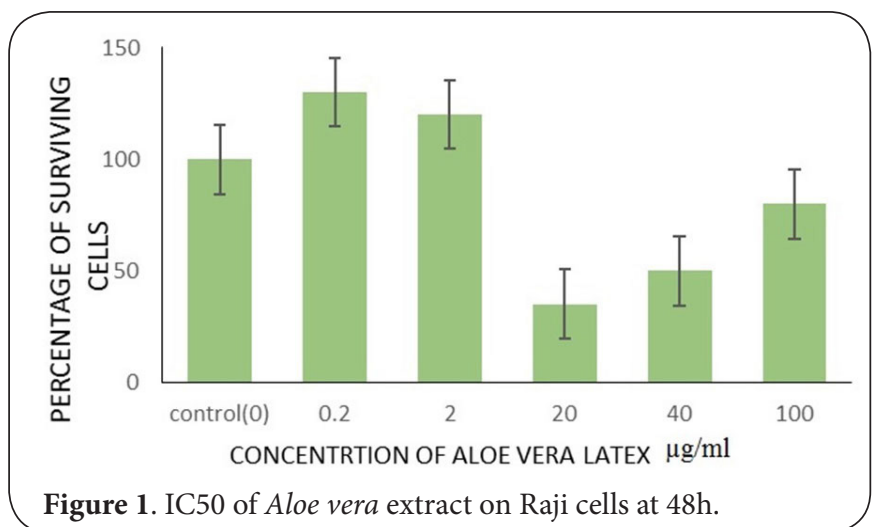

Figure 1. IC50 of Aloe vera extract on Raji cells at $48 \mathrm{~h}$.

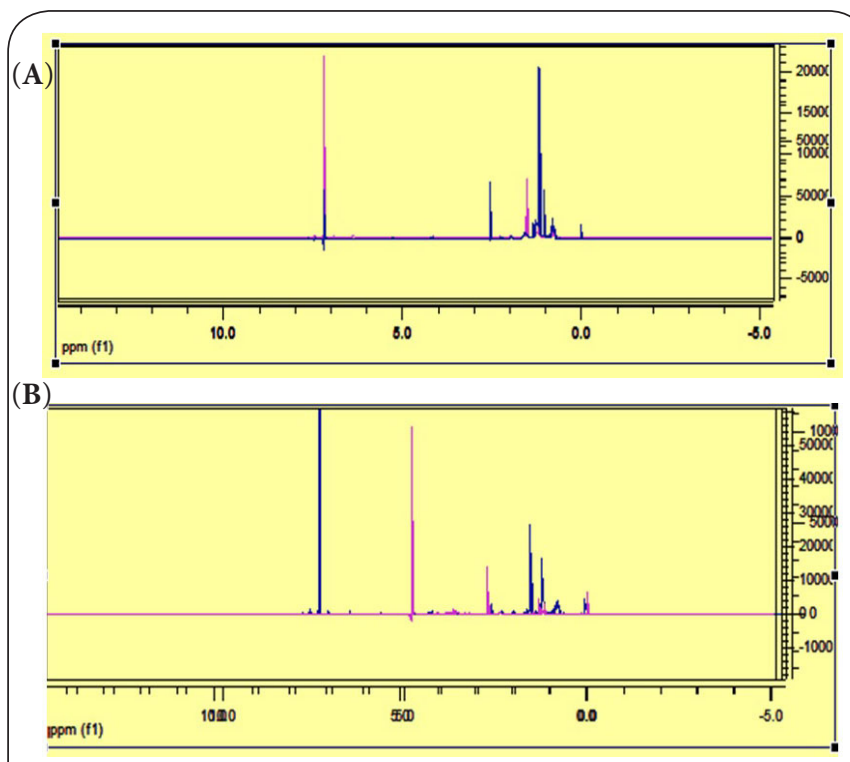

Figure 2. (A) Superimposed ${ }^{1} \mathrm{HNMR}$ spectra of hydrophilic phase of Aloe vera treated Raji cells and controls.

(B) Superimposed ${ }^{1} \mathrm{HNMR}$ spectra of hydrophobic phase of Aloe vera treated Raji cells and Controls.

cancer activity of Aloe vera on Raji cells was exhibited by IC50 of $40 \mu \mathrm{g} / \mathrm{ml}$ in vitro confirming the above results.

Metabolomic studies done in this survey also revealed the mechanism of activity of Aloe vera extract on Raji cells. Levels of some amino acids had altered between the two groups (normal and treated) and the metabolic cycles in which they participated were identified by the Metaboanalyst website. These amino acids were involved primarily in protein biosynthesis, a cycle which was affected in both the hydrophilic and hydrophobic extracts. A number of glycoproteins present in Aloe vera gel have been described as antitumor and anti-ulceric and seen to increase proliferation of normal human dermal cells [18]. A substance named Aloin, an anthroquine and the main ingredient of Aloe vera has been shown to possess anticancer potential activities, as it blocks signal transducers and is an activator of transcription 3 activation by inhibiting 
Noorolahi et al. Journal of Metabolomics 2016,
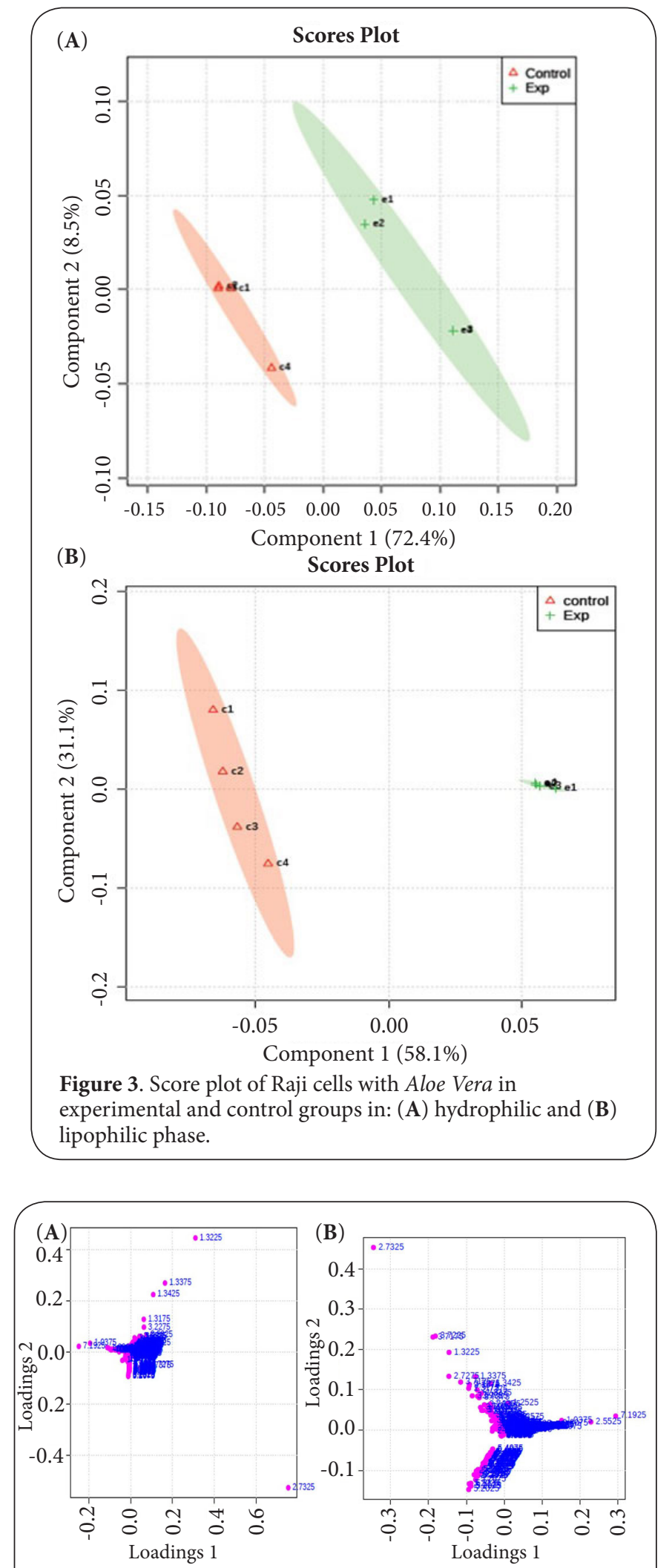

Figure 4. Loading plot of Raji cells with Aloe Vera in experimental and control groups in: (A) hydrophilic and (B) lipophilic phase.

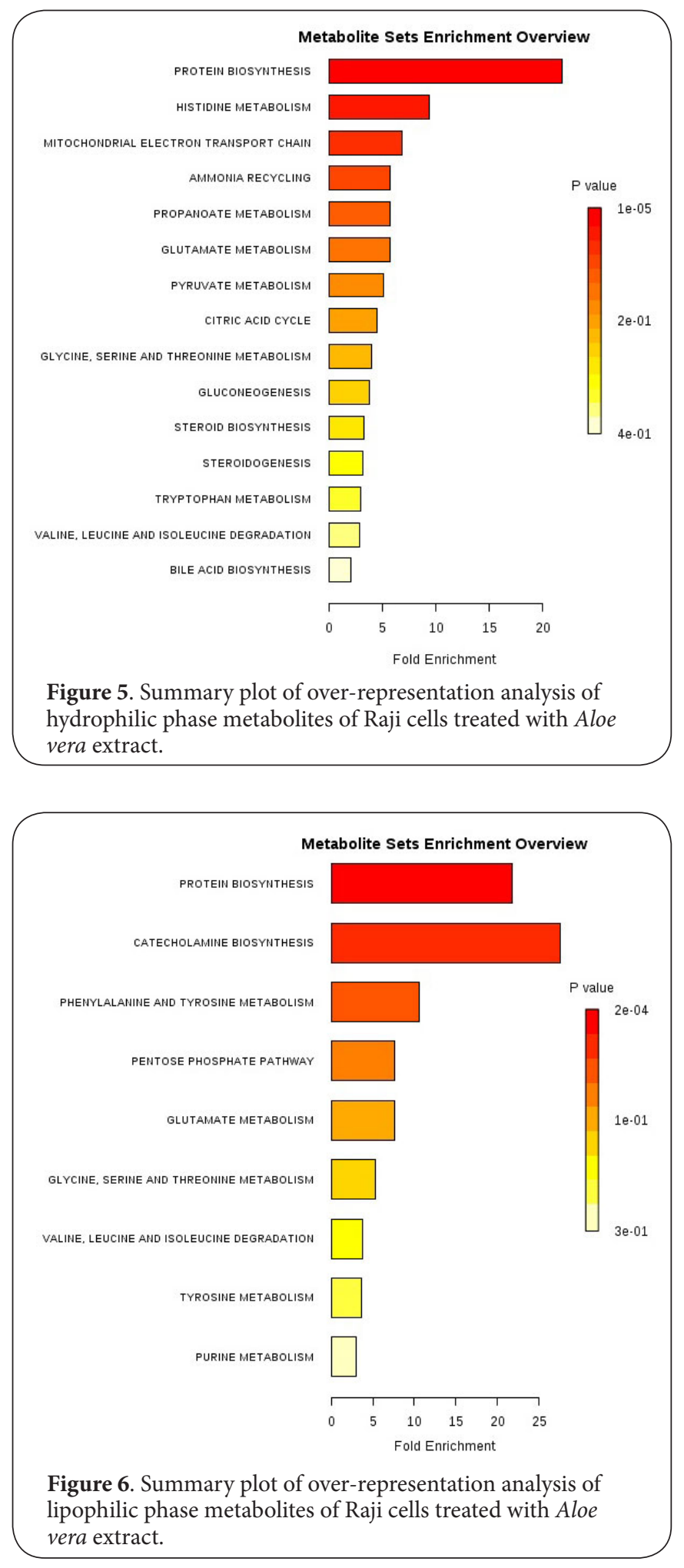

tumor angiogenesis and growth demonstrating its potential as a drug candidate for cancer therapy [17]. Investigations carried out in mice fed with fresh leaf pulp extract have shown Aloe vera to be an inducer of phase-Il enzyme system which 
Noorolahi et al. Journal of Metabolomics 2016,

http://www.hoajonline.com/journals/pdf/2059-0008-2-1.pdf

Table 1. Altered metabolites of treated group with drug in hydrophilic phase.

\begin{tabular}{llll}
\hline No. & Chemical shift & Metabolite name & HMDB No. \\
\hline 1 & $1.3175,1.3225$ & L-Lactic acid & HMDB00190 \\
2 & 3.5825 & L-Threonine & HMDB00167 \\
3 & $0.7575,0.7675,0.7725$ & Cholesterol & HMDB00067 \\
4 & 7.1875 & L-Tryptophan & HMDB00929 \\
5 & $1.0375,1.3425,1.0325$, & L-Valine & HMDB00883 \\
& 1.0425 & & \\
6 & 1.3375 & L-Alloisoleucine & HMDB00557 \\
7 & 7.0925 & L-Histamine & HMDB00177 \\
8 & 2.7325 & Succinic acid & HMDB00254 \\
\hline
\end{tabular}

Table 2. Altered metabolites of treated group with drug in lipophilic phase.

\begin{tabular}{llll}
\hline No. & Chemical shift & Name of metabolite & HMDB No. \\
\hline 1 & $0.2225,0.2025$ & D-Ribose 5-phosphate & HMDB01548 \\
2 & 0.8075 & $\begin{array}{l}\text { 2-Hydroxy-3-methylbutyric } \\
\text { acid }\end{array}$ & HMDB00407 \\
3 & 3.7125 & L-Leucine & HMDB00687 \\
4 & 7.1975 & L-Tyrosine & HMDB0605 \\
5 & 1.3225 & L-Threonine & HMDB00167 \\
6 & 2.7275 & Succinic acid semialdehyde & HMDB01259 \\
\hline
\end{tabular}

help in detoxification and are associated with carcinogen metabolism. The microsomal and cytosolic proteins were increased in the Aloe vera treated mice indicating the possibility of its involvement in the initiation of protein synthesis [19].

Aloin treatment is shown to inhibit the secretion of vascular endothelial growth factor (VEGF), thus inhibiting proliferation and migration of endothelial cells. VEGF is one of the most important proangiogenic cytokines known and well distinguished as a provoker of tumor neovascularization. VGEF production is shown to be regulated by histamine which is produced from histidine via the enzyme L-histidine decarboxylase $[\mathbf{2 0}, \mathbf{2 1}]$. Histidine metabolism is one of the cycles detected by our analysis.

L-tyrosine is involved in the catecholamine cycle, another metabolic cycle seen to differ with Aloe vera's action on Raji cells. There have been reports since 1991 that catecholamines and their metabolites are present in single lymphocytes and extracts of T-and B-cell clones as detected by capillary electrophoresis and electrochemical detection. Pharmacological inhibition of tyrosine hydroxylase diminishes perceived catecholamine levels, suggesting catecholamine synthesis by lymphocytes [22]. L-tyrosine is the substrate for tyrosine hydroxylase and is detected in this study.

Succinic acid participates in the mitochondria electron transport chain system. The protective effect of Aloe vera gel on the permeability transition pore in the inner membrane of rat liver mitochondria in vitro has been described. These findings indicate that Aloe vera gel modulates the effect of calcium by moderating the mitochondrial pore opening which is needed in situations that requires tissue wastage such as in cancer treatment [23].

Degradation of leucine, isoleucine and valine identified in this study has been reported earlier as an important step in cancer metabolism. An investigation carried out on breast cancer cells using microarray has shown this to be the second most important metabolic cycle involved $[14,24]$. These amino acids are also present in the Aloe vera gel and are likely to be utilized by Raji cells [25].

Gutamate is an antioxidant and is also a source of amino groups for nonessential amino acids like glycine, aspartate, alanine and serine which are required for macromolecular synthesis [26]. The tricarboxylic acid cycle (TCA), the main source of a-ketoglutarate in glutamine consuming cells is glutamate which is also an intermediate for TCA cycle and dioxygenases substrate which can cause protein and DNA modifications. These dioxygenases enzymes include histone demethylases, 5-methylcytosine hydroxylases and prolyl hydroxylases whose requirement for a-ketoglutarate maybe just a fraction of total a-ketoglutarate consumption which makes this metabolite an essential component of cell signaling and epigenetic networks [27]. Aloe vera affects glutamate metabolism by disturbing these crucial networks.

Phenylalanine and tyrosine metabolism was one of the cycles involved and there are reports of its importance in oesphaegal cancer in a serum metabolic study ([28]). Infact, limitation of pheylalanine and tyrosine amino acids is seen to inhibit prostrate cancer [29].

The pentose phosphate pathway(PPP) is also seen in this study. Energy metabolism is readjusted in many human cancers that bestows many advantages to cancer cells, which include ATP generation, promotion of biosynthesis, detoxification and support of rapid proliferation. Glucose catabolism is carried out by the PPP. It directs the flux of glucose to its oxidative branch and produces a reduced form of nicotinamide adenine dinucleotide phosphate (NADPH), an essential reductant in anabolic processes. It is now obvious that PPP has a very important role in regulation of growth of cancer cells by supplying cells with ribose-5-phosphate and also the NADPH required, reductive biosynthesis, detoxification of intracellular reactive oxygen species and ribose biogenesis. It can be concluded that any disturbance in the PPP directly contributes to proliferation of cancer cells, their endurance and weakness. Recent work has proved that regulation oncogenically/or metabolically of PPP is by numerous factors, including proteins such as oncoproteins, tumor suppressors and intracellular metabolites. Cancer cell growth and its survival is due to disturbance of PPP flux. PPP is one of the significant cycles identified by Aloe vera [30].

Earlier work implemented on the metabolic effect of ginger on Raji cells with an IC50 of $1 \mathrm{mg} / \mathrm{ml}$. It is interesting that the only common metabolic pathway identified by Aloe vera and ginger is protein biosynthesis which is directly involved in cell proliferation. Ginger seemed to act primarily on the 
Noorolahi et al. Journal of Metabolomics 2016,

http://www.hoajonline.com/journals/pdf/2059-0008-2-1.pdf

doi: $10.7243 / 2059-0008-2-1$

different glucose cycles, whereas Aloe vera acts mainly on amino acid cycles and the mitochondria. It seems that the two medicinal herbs act on different metabolic pathways to inhibit Raji cell growth [7].

\section{Conclusion}

Aloe vera exhibited inhibitory effect on Raji cells with an IC50 of $40 \mu \mathrm{g} / \mathrm{ml}$. It affects primarily the protein biosynthetic pathway, different amino acid pathways, catecholamine synthesis, mitochondrial transport chain and pentose phosphate pathway exhibiting its unique mechanism of action.

\section{List of abbreviations}

'HNMR: $1 \mathrm{H}$ Nuclear Magnetic Resonance

MTT: MTT 3-(4,5-dimethylthiazol-2-yl)-2,5-diphenyltetrazolium bromide

MS: Mass spectrometry

NOESY: Nuclear Overhauser Spectroscopy

MATLAB: Matrix laboratory

PLS-DA: Partial linear square-discriminate analysis

TCA: Tricarboxylic acid cycle

PPP: Pentose phosphate pathway

\section{Competing interests}

The authors declare that they have no competing interests.

\section{Authors' contributions}

\begin{tabular}{|l|c|c|c|c|c|c|c|c|c|c|}
\hline $\begin{array}{l}\text { Authors' } \\
\text { contributions }\end{array}$ & SMN & SS & MM & MA & NAR & MA2 & FV & HH & SM & ZZ \\
\hline $\begin{array}{l}\text { Research concept } \\
\text { and design }\end{array}$ & -- & -- & -- & -- & -- & -- & -- & $\checkmark$ & -- & $\checkmark$ \\
\hline $\begin{array}{l}\text { Collection and/or } \\
\text { assembly of data }\end{array}$ & $\checkmark$ & -- & $\checkmark$ & -- & $\checkmark$ & -- & -- & -- & -- & -- \\
\hline $\begin{array}{l}\text { Data analysis and } \\
\text { interpretation }\end{array}$ & -- & -- & -- & $\checkmark$ & -- & $\checkmark$ & -- & -- & -- & - \\
\hline Writing the article & -- & -- & -- & -- & -- & -- & -- & -- & -- & $\checkmark$ \\
\hline $\begin{array}{l}\text { Critical revision of } \\
\text { the article }\end{array}$ & -- & $\checkmark$ & -- & -- & -- & -- & -- & -- & -- & -- \\
\hline $\begin{array}{l}\text { Final approval of } \\
\text { article }\end{array}$ & -- & -- & -- & -- & -- & -- & -- & -- & $\checkmark$ & -- \\
\hline Statistical analysis & -- & -- & -- & -- & $\checkmark$ & -- & $\checkmark$ & -- & -- & -- \\
\hline
\end{tabular}

Publication history

Senior Editor: Edward A. Ratovitski, The Johns Hopkins University, USA. Received: 06-Jun-2016 Final Revised: 30-Jun-2016

Accepted: 12-Jul-2016 Published: 27-Jul-2016

\section{References}

1. Rajeswari R, Umadevi M, SharmilaRahale C,Pushpa R, Selvavenkadesh S,. Sampath Kumar KP and Bhowmik D. Aloe vera: The Miracle Plant Its Medicinal and Traditional Uses in India. J. of Pharmacognosy and Phytochem. 2012; 1:118-124. I Article

2. Radha MH and Laxmipriya NP. Evaluation of biological properties and clinical effectiveness of Aloe vera: A systematic review. J Tradit Complement Med. 2015; 5:21-6. | Article | PubMed Abstract | PubMed FullText

3. Alawode T.T. An overview of the anti-cancer properties of some plants used in traditional medicine in Nigeria. Int. Res. J. of Biochem.andBioinf. 2013; 3:7-14. | Article

4. Abdel-Aziz AF, Osman $Y$ and Jobara A. Antitumor Activity of Natural Compounds Against Ehrlich Ascites Carcinoma in Swiss Albino Mice.
Ind. J. of Appl. Res. 2014; 4:556-560. I Pdf

5. Li X, Yang X, Liu Y, Gong N, Yao W, Chen P, Qin J, Jin H, Li J, Chu R, Shan $L$, Zhang $R$, Zhang $W$ and Wang $H$. Japonicone $A$ suppresses growth of Burkitt lymphoma cells through its effect on NF-kappaB. Clin Cancer Res. 2013; 19:2917-28. | Article | PubMed

6. Horgan RP and Kenny LC. 'Omic' technologies: genomics, transcriptomics, proteomics and metabolomics. The Obstet.\&Gynaec. 2011; 13:189-195. | Article

7. Parvizzadeh N, Sadeghi S, Irani S, Iravani A, Kalayee Z, Rahimi NA, Azadi M and Zamani Z. A Metabonomic Study of the Effect of Methanol Extract of Ginger on Raji Cells Using (1)HNMR Spectroscopy. Biotechnol Res Int. 2014; 2014:572534. | Article | PubMed Abstract | PubMed FullText

8. Chandegara VK and Varshney AK. Aloe vera L.: processing and products: a review. Int. J. of Med. and Aromatic Plants. 2013; 3:492-506. | Pdf

9. RafieeMehr HR. Evaluation of Cytotoxic Effect of Zinc on Raji Cell-Line by MTT ASSAY. Iranian J. of Tox. 2011; 4:390-396. I Pdf

10. Palama IE, Musaro M, Coluccia AM, D’Amone $S$ and Gigli G. Cell Uptake and Validation of Novel PECs for Biomedical Applications. J Drug Deliv. 2011; 2011:203676. | Article | PubMed Abstract | PubMed FullText

11. Zha J, Chen F, Dong H, Shi P, Yao Y, Zhang Y, Li R, Wang S, Li P, Wang W and $X u B$. Disulfiram targeting lymphoid malignant cell lines via ROS-JNK activation as well as Nrf2 and NF-kB pathway inhibition. J Trans/ Med. 2014; 12:163. | Article | PubMed Abstract | PubMed FullText

12. Gottschalk M, Ivanova G, Collins DM, Eustace A, O'Connor R and Brougham DF. Metabolomic studies of human lung carcinoma cell lines using in vitro (1)H NMR of whole cells and cellular extracts. NMR Biomed. 2008; 21:809-19. | Article | PubMed

13. Gao H, Fang X, Mao S, Yuan H, Zhao S, Cheng G, Yu J and Youru D. Conformation and dynamics of polyoxyethylene lauryl ether (Brij-35) chains in aqueous micellar solution studied by 2D NOESY and 1H NMR relaxation. Sci.China Chem.2002; 45:143-150. I Pdf

14. Viant MR. Improved methods for the acquisition and interpretation of NMR metabolomic data. Biochem Biophys Res Commun. 2003; 310:9438. | Article | PubMed

15. Radha MH and Laxmipriya NP. Evaluation of biological properties and clinical effectiveness of Aloe vera: A systematic review. J Tradit Complement Med. 2015; 5:21-6. | Article | PubMed Abstract | PubMed FullText

16. Shalabi M, Khilo H, Zakaria MM, Elsebhaei MG, Abdu W and Awadin W. Anticancer activity of Aloe vera and Calligonumcomosum extracts separetely on hepatocellular carcinoma cells. Asian Pacific J. of Trop. Biomed. 2015; 5:375-381. | Article

17. Lin JG, Chen GW, Li TM, Chouh ST, Tan TW and Chung JG. Aloe-emodin induces apoptosis in T24 human bladder cancer cells through the p53 dependent apoptotic pathway. J Urol. 2006; 175:343-7. | Article | PubMed

18. Yagi A, Kabash A, Mizuno K, Moustafa SM, Khalifa TI and Tsuji H. Radical scavenging glycoprotein inhibiting cyclooxygenase-2 and thromboxane A2 synthase from aloe vera gel. Planta Med. 2003; 69:269-71. | Article I PubMed

19. Singh RP, Dhanalakshmi S and Rao AR. Chemomodulatory action of Aloe vera on the profiles of enzymes associated with carcinogen metabolism and antioxidant status regulation in mice. Phytomedicine. 2000; 7:20919. | Article | PubMed

20. Ghosh AK, Hirasawa N and Ohuchi K. Enhancement by histamine of vascular endothelial growth factor production in granulation tissue via H(2) receptors. Br J Pharmacol. 2001; 134:1419-28. | Article | PubMed Abstract | PubMed FullText

21. Pan $\mathrm{Q}$, Pan $\mathrm{H}$, Lou $\mathrm{H}, \mathrm{Xu} Y$ and Tian L. Inhibition of the angiogenesis and growth of Aloin in human colorectal cancer in vitro and in vivo. Cancer Cell Int. 2013; 13:69. | Article | PubMed Abstract | PubMed FullText

22. Bergquist J, Tarkowski A, Ekman R and Ewing A. Immunology Discovery of endogenous catecholamines in lymphocytes And evidence for catecholamine regulation of lymphocyte function via an autocrine loop. P.N.A.S.USA. 1994; 91:12912-12916. | Article

23. Akomolafe SF, Olanlokun JO, Adesina AJ and Olorunsogo OO. Protective 
Noorolahi et al. Journal of Metabolomics 2016,

http://www.hoajonline.com/journals/pdf/2059-0008-2-1.pdf

effect of Aloe vera gel on the permeability transition pore in the inner membrane of rat liver mitochondria in vitro. Drug Chem Toxicol. 2014; 37:415-9. | Article | PubMed

24. Schramm G, Surmann EM, Wiesberg S, Oswald M, Reinelt G, Eils R and Konig R. Analyzing the regulation of metabolic pathways in human breast cancer. BMC Med Genomics. 2010; 3:39. | Article | PubMed Abstract | PubMed FullText

25. Sahu P, Giri D, Singh R, Pandey P, Gupta S, Shrivastava A, Kumar A and Pandey K. Therapeutic and Medicinal Uses of Aloe vera: A Review. Pharmacology \&Pharmacy. 2013; 4:599-610. | Article

26. Yang C, Sudderth J, Dang T, Bachoo RM, McDonald JG and DeBerardinis RJ. Glioblastoma cells require glutamate dehydrogenase to survive impairments of glucose metabolism or Akt signaling. Cancer Res. 2009; 69:7986-93. | Article | PubMed Abstract | PubMed FullText

27. Hensley CT, Wasti AT and DeBerardinis RJ. Glutamine and cancer: cell biology, physiology, and clinical opportunities. J Clin Invest. 2013 123:3678-84. | Article | PubMed Abstract | PubMed FullText

28. Zhang X, Xu L, Shen J, Cao B, Cheng T, Zhao T, Liu X and Zhang H. Metabolic signatures of esophageal cancer: NMR-based metabolomics and UHPLC-based focused metabolomics of blood serum. Biochim Biophys Acta. 2013; 1832:1207-16. | Article | PubMed

29. Fu YM and Meadows GG. Specific amino acid dependency regulates the cellular behavior of melanoma. J Nutr. 2007; 137:1591S-1596. | Article I PubMed

30. Jiang P, Du W and Wu M. Regulation of the pentose phosphate pathway in cancer. Protein Cell. 2014; 5:592-602. | Article | PubMed Abstract | PubMed FullText

\section{Citation:}

Noorolahi SM, Sadeghi S, Mohammadi M, Azadi M, Rahimi NA, Vahabi F, Arjmand M, Hosseini H, Mosallatpur S and Zamani Z. Metabolomic profiling of cancer cells to Aloe vera extract by ${ }^{1} \mathrm{HNMR}$ spectroscopy. $J$ Metabolomics. 2016; 2:1.

http://dx.doi.org/10.7243/2059-0008-2-1 